DOI: 10.20472/IAC.2018.038.002

\author{
NEŞE ARAL \\ Uludag University, Turkey \\ MINE AYDEMIR \\ Uludag University, Turkey
}

\title{
INVESTIGATION OF CUSTOMER LOYALTY IN TOURISM
}

\begin{abstract}
:
Aim: The aim of this study is to investigate customer loyalty in the tourism sector by taking into consideration quality of service and customer satisfaction.

Method: A questionnaire was applied to measure customer loyalty, quality of service and customer satisfaction. 369 customers answered the questionnaire voluntarily. Approximately $42 \%$ of customers who filled out the questionnaire were male. The data were analyzed using the structural equations modeling.

Results: The customer satisfaction and quality of service have been used to explain customer loyalty. A structural equation model containing these latent variables have been constructed and estimated. The signs of the standardized coefficients have been found to be in accordance with the expectations. Quality of service has directly positively affected customer loyalty $(\beta=0.51 ; p<.01)$. Quality of service has directly positively affected customer satisfaction $(\beta=0.71 ; p<.01)$. Customer satisfaction has affected customer loyalty directly in the positive direction $(\beta=0.29 ; p<.01)$. Quality of service has indirectly affected customer loyalty both directly and through customer satisfaction. $55 \%$ of customer loyalty was explained by the quality of service and customer satisfaction. $51 \%$ of customer satisfaction was explained by service quality. The goodness of fit index values was acceptable. The results were $\mathrm{X} 2 / \mathrm{df}=1.846 ; \mathrm{GFI}=0.96 ; \mathrm{CFI}=0.98 ; \mathrm{RMSEA}=0.05 ; \mathrm{SRMR}=0.04$.

Conclusion: This study focused on customer satisfaction and quality of service that affect customer loyalty in tourism. According to the results, customer loyalty was positively affected by the quality of service and customer satisfaction. The results highlighted that increasing service quality and customer satisfaction increases customer loyalty.
\end{abstract}

\section{Keywords:}

Quality of service, Customer satisfaction, Customer loyalty, Tourism

JEL Classification: C10, L83 